\title{
Morphometric analysis of the intimal reaction after stent implantation in iliac arteries submitted to angioplasty in pigs ${ }^{1}$
}

\author{
Análise morfométrica da reação intimal secundária ao implante de stent em artérias \\ ilíacas submetidas à angioplastia em suínos
}

\author{
Cyro Castro Júnior ${ }^{2}$, Adamastor Humberto Pereira ${ }^{3}$, Márcio Bastiani Pasa ${ }^{4}$ \\ 1. Research from Federal University of Rio Grande do Sul (UFRGS), Post-Graduation Program in Surgery. Porto Alegre-RS. Brazil. \\ 2. Vascular and Endovascular Surgeon, Master in Surgery. Porto Alegre-Rio Grande do Sul. Brazil. \\ 3. Vascular and Endovascular Surgeon, Professor of Surgery of UFRGS. Porto Alegre-Rio Grande do Sul. Brazil. \\ 4. Vascular Surgeon, Master in Surgery. Porto Alegre-Rio Grande do Sul. Brazil.
}

\begin{abstract}
Purpose: To compare through digital morphometry, the intimal thickening of the common ilíac arteries (CIA) in pigs, submitted to angioplasty and angioplasty followed by stent implantation. Methods: Angioplasty was performed in 10 pigs in both CIA, followed by a stent implantation in the left CIA. After four weeks, the aorto-iliac segment was dissected. Histologic slices where divided in three groups: left CIA in the area of the proximal (group 1) and distal (group 2) implantation site of the stent and the region of angioplasty in the right CIA (group 3). The histological slices were digitalized to be analyzed by morphometry with calculation of the luminal, intimal and media layers areas. Descriptive statistics analysis was performed through average and standard deviation of areas on each group, using ANOVA, with LSD Post-Hoc test $(\mathrm{p} \leq 0.05)$. Results: A significant statistic difference was observed when the median area of intimal layer of the groups 1 and 2 where compared with group 3 and in the media layer area of the groups 1 and 2 when compared with group 3. No difference was observed in luminal areas among the three groups. Conclusion: Angioplasty followed by stent insertion produces an intimal thickening larger than that observed after simple angioplasty. However, the area of the media layer is smaller in the "angioplasty plus stent” group and there is no significant change in the luminal area among the three groups. Key words: Angioplasty. Stents. Constriction, Pathologic. Vascular Diseases. Animal Experimentation.
\end{abstract}

\section{RESUMO}

Objetivo: Analisar, por meio da morfometria digital, o espessamento intimal das artérias ilíacas comuns (AIC) de suínos, submetidas à angioplastia e à angioplastia seguida do implante de stent. Métodos: Em dez suínos, foi realizada a angioplastia da AIC bilateral, seguida do implante do stent na AIC esquerda. Após quatro semanas, o segmento aorto-ilíaco foi retirado. As lâminas histológicas foram divididas em três grupos: segmento proximal (grupo 1) e distal (grupo 2) do local de implante do stent na AIC esquerda e a área da angioplastia da AIC direita (grupo 3). As imagens das lâminas foram digitalizadas e analisadas por programa de morfometria com cálculo das áreas luminal, da camada íntima e da camada média dos cortes histológicos. A análise estatística foi realizada através de média e desvio padrão das áreas em cada grupo, utilizando ANOVA, com teste Post-Hoc LSD ( $\leq \leq 0,05)$. Resultados: Na análise das médias das áreas obtidas, foi encontrada diferença estatisticamente significativa quanto à camada íntima dos grupos 1 e 2, quando comparados ao grupo 3 e em relação à camada média dos grupos 1 e 2 quando comparados ao grupo 3 e não se observou diferença significativa nas médias das áreas luminais dos três grupos. Conclusão: A angioplastia seguida do implante do stent gerou um espessamento intimal maior do que aquele produzido apenas pela angioplastia, porém, a área da camada média apresentou-se diminuída nos grupos “angioplastia + stent”; a luz arterial não apresentou diferença entre estes grupos.

Descritores: Angioplastia. Contenedores. Constrição Patológica. Doenças Vasculares. Experimentação Animal.

\section{Introduction}

Peripheral obstructive disease of the lower extremities is an important cause of morbidity that affects more than 10 million people in the USA ${ }^{1}$. Open revascularization surgery is still the best choice in the management of most of the peripheral obstructive arterial disease, although endovascular procedures, due to the low morbidity and improving success rate, is playing a prominent part in primary or complementary treatment ${ }^{2,3}$. The initial success rate of percutaneous transluminal angioplasty (PTA) is relative high but a percentage of patients submitted to this procedure subsequently develop restenosis during the first year. Amongst the alternative techniques, the use of stents has been recognized as an effective mean to improve patency over the medium and long term. Unfortunately restenosis again still limits the wider application of these devices $^{2-5}$. This study proposes, by means of a digital 
morphometric analysis, to measure the parietal thickening after angioplasty and to compare it with the combination of angioplasty plus insertion of a self-expanding stainless steel stent in the pig CIA. In addition, the luminal area between groups was measured to determine if a residual stenosis remained.

\section{Methods}

The study was conducted using ten healthy Landrace x Large White pigs approximately $20 \mathrm{~kg}$ in weight each, with the previous ethical approval from Research and Post Graduation Group (GPPG) of the Clinicas Hospital of Porto Alegre (UFRGS) and under adequate treatment according to the Law. For the experiments, "Z" shaped, autoexpandable stents manufactured of 316L stainless steel, 3 $\mathrm{cm}$ long capable of expanding to a diameter of $5 \mathrm{~mm}$ were used. The Mechanical Transformation Laboratory of the UFRGS, University’s Engineering School, has manufactured all the devices. The surgical procedures were performed under inhalant general anesthesia in an open system without reinhalation. The animals were not fed for six hours beforehand and were medicated with an intramuscular injection of midazolam $10 \mathrm{mg}$ and an intravenous injection of cefalotin $1 \mathrm{~g}$ before the procedure. An intravenous solution of $2.5 \%$ sodic thiopental was used for anesthetic induction and the animals were ventilated with oxygen and environmental air. Anesthesia was maintained with halothane and liquids were replaced by a glico-physiological solution. The experiment was divided into two phases.

\section{Phase 1}

- the infrarenal abdominal aorta was minimally dissected by laparotomy in the lower half of the abdomen. During the operation venous blood samples were collected for blood hematocrit, hemoglobin, leukocytes and serological tests (total cholesterol, fractions and triglicerids) and a full heparinization (100 UI/kg) was performed 10 minutes before the arterial manipulation;

- angioplasty of the right and left CIA was performed in sites not manipulated surgically. A $4 \mathrm{~mm}$ ballon catheter was inflated with $1,5 \mathrm{ml}$ of air for three periods of 1 minute at intervals of 30 seconds and a stent was implanted in the area of previous angioplasty in the left CIA;

- direct aortic suture repair and closure of the abdominal wall in layers;

- the animals were lodged in two stalls with flowing water and fed with the same ration.

\section{Phase 2}

- after four weeks, using the same pre-operative and anesthetic protocol of phase 1, new blood samples were taken and a laparotomy with ample dissection of the aorta and iliac vessels was performed. The surgical specimen containing the infrarenal abdominal aorta and the iliac arteries was removed in one block after a lethal dose of sulphate of magnesium had been administered under a general anesthesia;

- the surgical specimen was irrigated, under controled pressure, with a $\mathrm{NaCl} 0.9 \%$ solution and fixed in a formalin solution at $10 \%$.

For microscopic evaluation, two arterial segments 3 $\mathrm{mm}$ in length were transversally split at the proximal (group 1) and distal (group 2) margins of the left CIA stent, as well as a $3 \mathrm{~mm}$ segment of the right CIA (group 3) from the area where the angioplasty had been performed. These three groups of specimens were fixed in paraffin blocks and sliced into $4 \mu \mathrm{m}$ thick for the histological slices and stained with the Hematoxilin and Eosin (HE) and Verhoeff techniques. The images of the histological slices were digitalized using a conventional optical microscope with phototube, a closed circuit colour camera (Sony DXC $151^{\text {ò }}$ - Japan) and an IMAGE PROPLUS CAPTURE KIT ${ }^{\text {ò }}$ (Media Cybernetics USA), analogue-to-digital conversion board. This apparatus generated computer image files of $640 \mathrm{x} 480$ pixels, 24 bits, with twenty times microscopic amplification for the morphometric analysis which was carried out with the

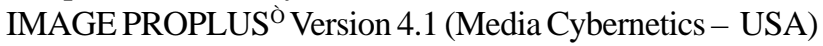
and IMAGE ${ }^{\mathrm{O}}$ (Scion Corporation - USA) software. The planimetry of the vascular lumen area, of the intimal layer area and the media layer area was performed automatically, without interference by the observer.

In each component of the group, the luminal area was obtained by direct measurement of the area delimited by the endothelium, while the intimal area was calculated by subtracting the luminal area from that delimited by the internal elastic lamina (IEL) and, finally, the area of the media layer by subtracting the luminal and the intimal areas from the area delimited by the external elastic lamina (EEL).

The exclusion criteria considered were animal death before the moment established for tissue collection, surgical complications either during or after the operation and technical failures in the preparation or processing of the tissues. The data analysis was performed using the descriptive statistical method of the software statistical packet SPSS for Windows ${ }^{\circledR}$ version 8 (MICROSOFT ${ }^{\circledR}$ - USA), using the average and standard deviations. To analyse the weights and the hematimetrical and serological values, the Student $t$ test was utilised on paired samples, while the morphological analysis results were obtained by the Analysis of Variance (ANOVA) method for the variations among the groups, and by Least Significant Difference (LSD) Post-Hoc test for the variations within the groups. A value of $5 \%(p \leq 0.05)$ was considered statistically significant.

\section{Results}

There were three exclusions due to animal death. During the two phases of the experiment the animals gained significant weight. Regarding the hematimetric and serological variants, only the HDL and triglicerids showed abnormal distribution between the two phases of the experiment. The variants in normal distribution and the 
triglicerid were not of statistical importance by the $t$ test. Only the HDL had a significant statistical difference.

Stent patency and that of the angioplasty region were checked by the presence of the distal pulse during the second phase of the experiment. The macroscopic evaluation of the specimens demonstrated that the stent was firmly attached to the aortic wall and was covered by a thin, translucent coverage. Morphometric and statistical analysis was carried on using the average and standard deviations of the media layer, intimal and luminal areas of the samples analysed, divided into groups as follows (Table 1):

- group 1: those concerning the proximal segment of the stent of the left CIA;

- group 2: those concerning the distal segment of the stent of the left CIA;

- group 3: those concerning the area submitted to angioplasty of the right CIA.

Comparing the luminal areas, no statistical significant differences were found among the groups (ANOVA). When the areas of the the intimal layers were compared, statistically significant differences were found between the groups (ANOVA, $\mathrm{p}<0.01$ ). Within the groups there were differences when group 1 (median $5.41 \pm 1.60 \mathrm{~mm}^{2}$ ) and 2 (median $5.25 \pm 1.20 \mathrm{~mm}^{2}$ ) were compared to group 3 (median $\left.0.65 \pm 0.43 \mathrm{~mm}^{2}\right)(\mathrm{LSD}, \mathrm{p}<0.01)$ (Figures 1 and 2).

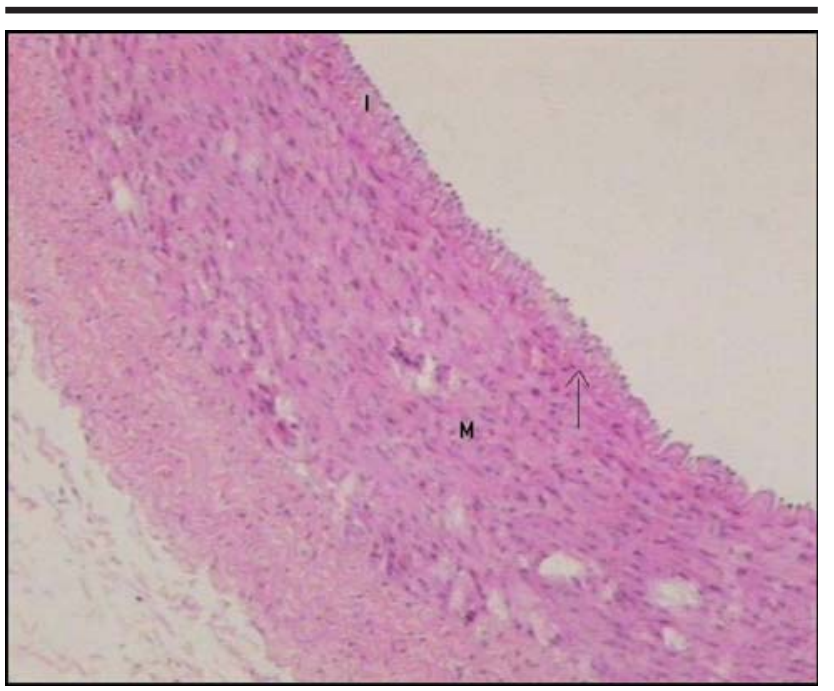

FIGURE 1 - Photomicrography of part of the right CIA four weeks after the angioplasty. HE staining. Original magnification of 100x. In detail, discrete thickening of the intimal layer (I). Arrow: internal elastic lamina, $\mathbf{M}$ : media layer

\section{Discussion}

Three deaths occurred due to bowel ischemia attributed to mesenteric traction during evisceration. The Minimal Incision Aortic Surgery (MIAS) technique, described by Turnipseed $^{6}$, was used and the approach to the aorta was performed with minimal viscera disturbance in an effort to minimise this problem. The hematimetric and serological
Comparing the media layers, there were statistically significant differences among the groups (ANOVA, $\mathrm{p}=0.05$ ). Within the groups, differences were found among group 1 (average $3.51 \pm 1.57 \mathrm{~mm}^{2}$ ) and 2 (average $3.70 \pm 1.10 \mathrm{~mm}^{2}$ ) when compared to group 3 (average $\left.5.59 \pm 2.03 \mathrm{~mm}^{2}\right)(\mathrm{LSD}, \mathrm{p}<0.05)$.

TABLE 1 - Tabulation of the morphological results

\begin{tabular}{lccc}
\hline VARIABLE & $\begin{array}{c}\text { AVERAGE } \\
\left(\mathrm{mm}^{2}\right)\end{array}$ & $\begin{array}{c}\text { SD } \\
\left(\mathrm{mm}^{2}\right)\end{array}$ & $\begin{array}{c}95 \% \mathrm{CI} \\
\left(\mathrm{mm}^{2}\right)\end{array}$ \\
\hline $\begin{array}{l}\text { GROUP 1 }(\mathrm{n}=7) \\
\text { Luminal area }\end{array}$ & 6.63 & 2.95 & $3.89-9.36$ \\
Intimal area & 5.41 & 1.60 & $3.93-6.90$ \\
Media area & 3.51 & 1.57 & $2.05-4.96$ \\
GROUP 2(n=7) & & & \\
Luminal area & 5.25 & 3.52 & $1.99-8.50$ \\
Intimal area & 5.25 & 1.20 & $4.14-6.36$ \\
Media area & 3.70 & 1.10 & $2.68-4.72$ \\
GROUP 3(n=7) & & & \\
Luminal area & 5.78 & 2.24 & $3.70-7.86$ \\
Intimal area & 0.65 & 0.43 & $0.25-1.05$ \\
Media area & 5.59 & 2.03 & $3.71-7.47$ \\
\hline
\end{tabular}

Observation: $\mathrm{n}=$ number of animals per group; $\mathrm{SD}=$ standard deviation; $\mathrm{CI}=$ confidence interval.

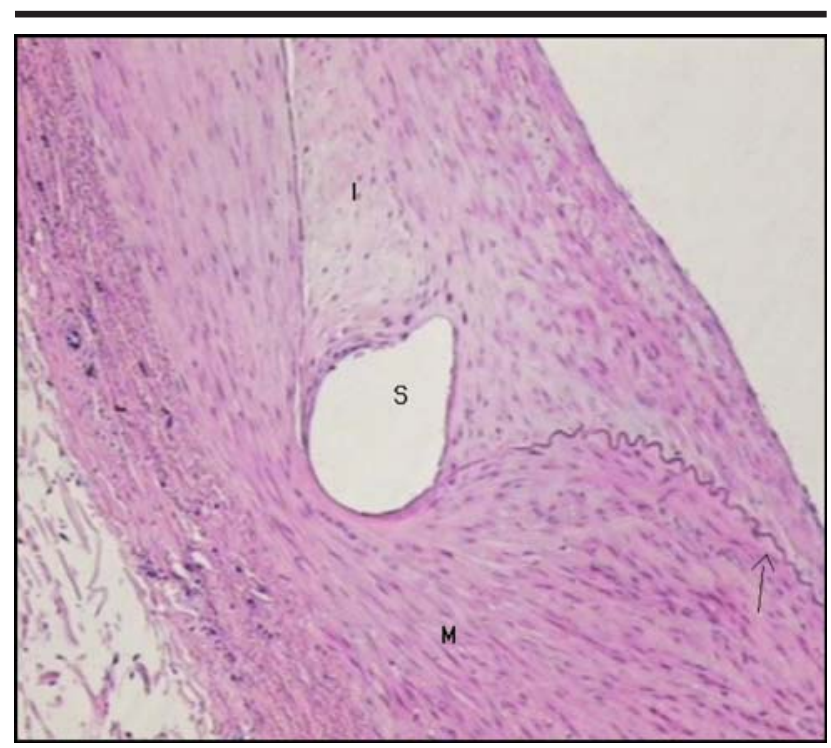

FIGURE 2 - Photomicrography of part of the left CIA four weeks after angioplasty and implantation of the stent. HE staining. Original magnification 100x. In detail, the location of a metallic fragment of the stent (S) covered by thickening of the intimal layer (I). Arrow: internal elastic lamina, $\mathbf{M}$ : media layer

values (lipids profile) did not show any statistically significant variation, apart from the HDL and it was inferred that these factors probably do not influence the development of the arterial lesion, These findings corroborates previous works in pigs $^{7}$. It is well established in humans that the degree of wall lesion caused by the stent or angioplasty is related to a variable degree of intimal tickening. The more the vessel is expanded, the greater the lesion produced and 
more neointimal layer is formed, but the enlargement of the vessel can accommodate a large amount of neointimal mass without luminal narrowing. Only if the consequent luminal loss, including the neointimal formation and vascular remodelation, exceeds the immediate luminal gain will a stenotic lesion be produced. This phenomenon has also been observed in peripheral arteries during experimental studies with animals models ${ }^{8}$. Some papers have described experiments on the iliac arteries of rabbits designed to study vascular lesions and the development of the design and structure of stents $^{9-11}$. However, larger animal models, such as pigs, seem to reflect better the pathology of human restenosis than do smaller animals ${ }^{8,12,13}$. Schwartz ${ }^{14,15}$ states that the phases of neointimal formation may be similar to humans in the pig model. These considerations agree with Costa et al. ${ }^{16}$, which emphasises the similarities between pigs and humans as regards to the cardiovascular anatomy, physiology and coagulation system. The major limitation of the animal models is the lack of pre-existing disease of the vascular wall, like arteriosclerosis in humans ${ }^{8}$. However, it seems that the findings related to the intimal hyperplasia after stent implantation in experimental animals maintained on an atherogenic diet were not different when compared a normal to a stenotic artery ${ }^{17}$. In a revision work on experimental models, De Meyer et al. ${ }^{18}$ described how studies based on endothelial lesions, like those produced by balloon abrasions, are useful for the analysis of the intimal thickness. There is not, however, any gold standard for the length of time balloons should be inflated during PTA in peripheral arterial vessels ${ }^{19}$. In our study, the inflation time was set at three periods of one minute each, spaced at intervals of thirty seconds. Obtaining histological slices after four weeks seems to be sufficient for studies of intimal thickening. The reaction to a lesion in the pig experimental model led to the formation of neointimal hyperplasia in one or two weeks, and the process is complete in twenty-eight days. In terms of histology, size and cellular density this is similar to what happens in humans ${ }^{13,16}$. Verheye et al. ${ }^{20}$, after implanting stents in the iliac and carotid arteries of pigs, conducted histological studies of one to six months, stating that within one month the vascular wall was completely covered by endothelial-type cells. In our laboratory, we have studied the intimal tickening in a series of conditions and the time interval of four weeks was used to study the arterial wall alterations ${ }^{7}$. Post et al. ${ }^{21}$ performed PTA or stent implants in atherosclerotic iliac arteries in micropigs, concluding that the luminal loss after PTA, when compared to the stent implant, was due principally to geometric remodelling in the first group and to intimal hyperplasia in the second. In clinical practice however, the insertion of a stent in the treatment of arteriosclerotic lesions is frequently preceded by angioplasty and this initiates the arterial remodeling process ${ }^{4}$. The real impact of the sum of these two types of aggression to the arterial wall is not clear. Harnek et al. ${ }^{22}$ obtained illiac arterial wall samples of pigs eight weeks after PTA alone, PTA followed by the implantation of nitinol stents, and the insertion of nitinol stents without prior PTA. They concluded that stent insertion without prior PTA caused less intimal hyperplasia than PTA followed by stent implantation. This experiment involved only three pigs in each group and in the results, they stated that the media arterial layer area after PTA followed by stent implant was bigger than that after angioplasty alone, a finding that we had not observed in our experiment. In the present study, the area of the media layer was smaller in the "angioplasty plus stent” (groups 1 and 2) than that of the "angioplasty" (group 3) and was statistically significant. These findings are in agreement with Cwikiel et al. ${ }^{23}$ where, in a pig model, PTA or stent insertion in iliac arteries were compared; it was observed that the number of proliferating smooth muscle cells in the media layer was significantly less after the stent insertion as compared to PTA alone. This work may be criticised with respect to the implantation of the stent without prior angioplasty, because this does not reproduce the more usual clinical situation, where stents are implanted after PTA. Furthermore these authors used samples obtained only twentyfour hours after the procedure and therefore a full observation of the proliferative process was not possible. Recent data from humans indicates that geometric remodeling plays an important role in restenosis after PTA. Grimm et al. ${ }^{24}$, in a random clinical test in humans, compared PTA with the PTA followed by stent implant in stenotic femoropopliteal lesions and found a greater residual stenosis in the first group, probably because the radial force of the stent prevented elastic remodelling. However, as time passed, this benefit was masked by the luminal loss, probably induced by intimal hyperplasia and patency became similar in both groups. These observations are in accordance with the present work, where a statistically significant difference was found in the area of the arterial intimal layer which was greater in the proximal and distal region of the stents (groups 1 and 2) than in the angioplasty (group 3). No significant differences, however, were observed in the luminal area probably because of the small amount of geometric remodelling which had occurred after the stent implant. The maintenance of adequate arterial luminal area after the implant of these devices is of fundamental importance for the patency of the procedure in the medium term. Later studies with fabriccovered stents, biodegradable devices and stents impregnated with medication in order to inhibit the neointimal growth may, more adequately, control the intimal thickening that occurs in the body of the stent after longer periods.

\section{Conclusion}

The angioplasty of the iliac artery in pigs, followed by the stent insertion produces a reaction in the arterial wall near the implant which is characterised by a greater intimal thickening than after angioplasty alone. However, the area of the media layer is smaller in the "angioplasty plus stent" groups than that of the "angioplasty" group. The intimal thickening is not sufficient to reduce the luminal area in the studied arteries.

\section{References}

1. Sanctis JT. Percutaneous Interventions for lower extremity peripheral vascular disease. Am Famacol Physician. 2001; 64: 1965-72.

2. Roller RE, Nimmrichter V, Trinker M, Seinost G, Schnedl WJ, Pilger E. Oxidative stress during peripheral angioplasty. Implication for late restenosis? Int Angiol. 2001; 20 (2): 131-5. 
3. Inoue S, Koyama H, Miyata T, Shigematsu H. Pathogenetic heterogeneity of in-stent lesion formation in human peripheral arterial disease. J Vasc Surg. 2002; 35: 672-8.

4. Goy JJ, Eeckhout E. Intracoronary stenting. Lancet. 1998; 351: 1943-9.

5. Roller RE, Janisch S, Kvas E, Schnedl WJ, Binder BR, Wojta J, Kominger, C. Smooth muscle cell migration promoting activity of plasma predicts restenosis in patients with peripheral arterial oclusive disease undergoing angioplasty. Thromb Haemost. 2000; 84: 1113-6.

6. Turnipseed WD, Carr SC, Tefera G, Acher CW, Hoch JR. Minimal incision aortic surgery. J Vasc Surg. 2001; 34: 47-53.

7. Grüdtner MA, Pereira AH, Costa LMF, Souza GG Argenta R, Longhi JA. Efeitos a curto prazo de stents não recobertos e recobertos com politetrafluoroetileno em aorta de suínos: um modelo experimental. Acta Cir Bras. 2004; 19(2): 126-30.

8. Andersen HR, Maeng M, Thorwest M, Falk E. Remodeling rather than neointimal formation explains luminal narrowing after deep vessel wall injury: insights from a porcine coronary (re)stenosis model. Circulation. 1996; 93 (9): 1716-24.

9. Rogers C, Karnovsky MJ, Edelman ER. Inhibition of experimental neointimal hyperplasia and thrombosis depends on the type of vascular injury and the site of drug administration. Circulation.1993; 88 (3): 1215-21.

10. Rogers C, Edelman ER. Endovascular stent design dictates experimental restenosis and thrombosis. Circulation. 1995; 91 (12): 2995-3001.

11. Edelman ER, Rogers C. Pathobiologic responses to stenting. Am J Cardiol. 1998; 81 (7A): 4E-6E.

12. Johnson GJ, Griggs TR, Badimon L. The utility of animal models in the preclinical study of interventions to prevent human coronary artery restenosis: analysis and recommendations. On behalf of the Subcommittee On Animal, Cellular and Molecular Models of Thrombosis and Haemostasis of the Scientific and Standardization Committee of the International Society on Thrombosis and Haemostasis. Thromb Haemost. 1999; 81 (5): 835-43.

13. Bayes-Genis A, Kantor B, Keelan PC, Altman JD, Lubbe DF, Kang JH, Schwartz RS. Restenosis and hyperplasia: animal models. Curr Interv Cardiol Rep. 2000; 2: 303-8.
14. Schwartz RS. The vessel wall reaction in restenosis. Semin Interv Cardiol. 1997; 2 (2): 83-8.

15. Schwartz RS. Pathophysiology of restenosis: interaction of thrombosis, hyperplasia and/or remodeling. Am J Cardiol. 1998; 81 (7A): 14E-17E.

16. Costa RFB, Fagundes DJ. Modelos experimentais de hiperplasia intimal: efeitos da radiação ionizante. Acta Cir Bras. 2002; 17 (3): 25-30.

17. Froelich JJ, Alfke H, Wilke A, Ramaswamy A, Barth KH, Hoppe M, Wagner HJ, Klose KJ. Effects of nitinol strecker stent placement on vascular response in normal and stenotic porcine iliac arteries. J Vasc Interv Radiol.1999; 10 (3): 329-38.

18. Meier GR, Bult H. Mechanisms of neointima formation: lessons from experimental models. Vasc Med. 1997; 2 (3): 179-89.

19. Zorger N, Manke C, Lenhart M, Finkenzeller T, Djavidani B, Feuerbach S, Link J. Peripheral arterial balloon angioplasty: effect of short versus long balloon inflation times on the morfologic results. J Vasc Interv Radiol. 2002; 13(4): 355-9.

20. Verheye S, Salame MY, Robinson KA, Post MJ, Carrozza JP Jr, Baim DS, Sigwart V, King SB3rd, Chronos NA. Short and long-term histopathologic evaluation of stenting using a self-expanding nitinol stent in pig carotid and iliac arteries. Cathet Cardiovasc Intervent.1999; 48: 316-23.

21. Post MJ, de Smet BJ, Van Der Helm Y, Borst C, Kuntz RE. Arterial remodeling after balloon angioplasty or stenting in an atherosclerotic experimental model. Circulation. 1997; 96(3): 996-1003.

22. Harnek J, Zoucas E, Stenram U, Cwikiel W. Insertion of self-expandable nitinol stents without previous balloon angioplasty reduces restenosis compared with PTA prior to stenting. Cardiovasc Intervent Radiol. 2002; 25 (5): 430-6.

23. Cwikiel W, Harnek J, Zoucas E, Stenram U. Proliferative response in smooth muscle cells after angioplasty or insertion of self-expanding stents. Acta Radiol. 1997; 38: 124-8.

24. Grimm J, Müller-Hülsbeck S, JahnkeT, Hilbert C, Brossmann J, Heller M. Randomized study to compare PTA alone versus PTA with palmaz stent placement for femoropopliteal lesions. J Vasc Intervent Radiol. 2001; 12: 935-41.

\section{Correspondence:}

Cyro Castro Júnior

Irmão Agnelo Chaves, 130

92020-080 Canoas - RS Brazil

Phones: (5551)426-1792/9977-3116

cyro@cefetrs.edu.br
Conflict of interest: none Financial source: FIPE - GPPG - UFRGS

Received: December 05, 2005

Review: January 10, 2006

Accepted: February 06, 2006

\section{How to cite this article:}

Castro Jr C, Pereira AH, Pasa MB. Morphometric analysis of the intimal reaction after stent implantation in iliac arteries submitted to angioplasty in pigs. Acta Cir Bras. [serial on the Internet] 2006 May-June;21(3). Available from URL: http://www.scielo.br/acb 